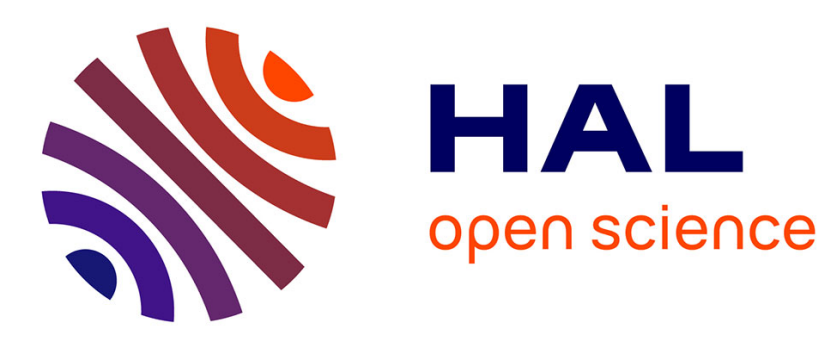

\title{
Hydrogen bonded supramolecular polymers in protic solvents: role of multitopicity
}

Marion Tharcis, Thomas Breiner, Joël Belleney, François Boué, Laurent Bouteiller

\section{- To cite this version:}

Marion Tharcis, Thomas Breiner, Joël Belleney, François Boué, Laurent Bouteiller. Hydrogen bonded supramolecular polymers in protic solvents: role of multitopicity. Polymer Chemistry, 2012, 3 (11), pp.3093. 10.1039/c2py20287e . hal-01696701

\section{HAL Id: hal-01696701 https://hal.science/hal-01696701}

Submitted on 26 Aug 2020

HAL is a multi-disciplinary open access archive for the deposit and dissemination of scientific research documents, whether they are published or not. The documents may come from teaching and research institutions in France or abroad, or from public or private research centers.
L'archive ouverte pluridisciplinaire HAL, est destinée au dépôt et à la diffusion de documents scientifiques de niveau recherche, publiés ou non, émanant des établissements d'enseignement et de recherche français ou étrangers, des laboratoires publics ou privés. 


\title{
Hydrogen bonded supramolecular polymers in protic solvents: role of multitopicity
}

\author{
Marion Tharcis, ${ }^{a}$ Thomas Breiner, ${ }^{b}$ Joël Belleney, ${ }^{a}$ François Bouéc ${ }^{c}$ and Laurent Bouteiller*a
}

We describe the synthesis of macromolecular amphiphiles of various molar masses containing well-defined hydrophobic groups incorporating urea moieties. All compounds have the same proportion of associative hydrophobic groups and 10 solubilising POE chains. However, a strong influence of both the number of associative groups per chain and its polydispersity is demonstrated. In water, where the interactions between stickers are strong, the monomer (bearing a single sticker) self-assembles into filaments, but all 15 other compounds with more than one sticker per chain are insoluble. In methanol, where the interactions between stickers are weaker, neither the monomer nor the monodispersed dimer are assembled, whereas polydispersed chains with an average number of stickers per chain of 2 or 3 20 self-assemble into filaments, leading to macroscopic gelation.

\section{Introduction}

Hydrogen bonding interactions in aqueous media are often very weak because of the competition from water molecules, but they can still have a decisive effect on self-assemblies 25 when used in combination with other interactions. DNA and RNA duplex formation are well-known examples where the fine control of the assembly derives from the directionality and specificity of base pairing, even though the energetic contribution from hydrogen bonds is much weaker than that 30 from base stacking interactions. ${ }^{1}$ The combination of hydrogen bonding and stacking interactions has also been used in synthetic heterocyclic systems to assemble columnar architectures with unprecedented structural control. ${ }^{2}$ In the case of amphiphiles with a hydrophobic part made from 35 flexible alkyl chains, the introduction of hydrogen bonds within the hydrophobic domains through urea groups has been shown to dramatically increase the viscosity of aqueous solutions, ${ }^{3,4}$ and to enable self-sorting between amphiphiles of distinct structures. ${ }^{5}$ The rheological properties of these low 40 molar mass compounds result from the formation of well structured worm-like micelles, that become entangled at high enough concentrations (Fig. 1a).

Another popular approach to form viscous solutions or gels, consists in decorating water soluble high molar mass ${ }_{45}$ polymers with hydrophobic groups. ${ }^{6}$ In this case, useful rheological properties are obtained when the hydrophobic groups assemble into spherical micelles creating physical intermolecular cross-links (Fig. 1b).

Our aim is to investigate the properties of systems 50 combining both design elements, i.e. macromolecules with hydrophobic groups able to form very long anisotropic hydrophobic domains (Fig. 1c). In this article, we report the synthesis of macromolecular amphiphiles of various molar masses containing well-defined hydrophobic groups that 55 incorporate urea moieties. The water solubility of these polymers is unfortunately not sufficient to test the proposed concept, however a strong effect of the multitopicity is revealed in polar organic solvents such as methanol.

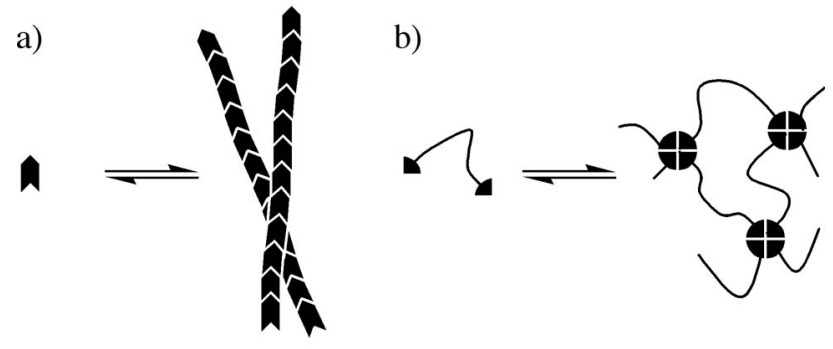

c)
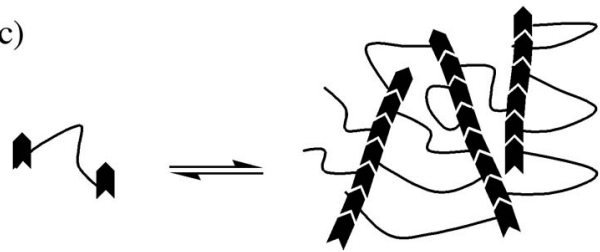

60 Fig. 1 Schematic assemblies formed by some amphiphiles: low molar mass compounds incorporating hydrogen bonds within a single hydrophobic group (a); polymers bearing multiple hydrophobic groups (b); polymers bearing multiple hydrophobic groups incorporating hydrogen bonds (c).

\section{${ }_{65}$ Experimental Part}

Synthesis

11-tert-butoxycarbonylamino-undecanoic acid (1). Adapted from Leigh. ${ }^{7}$ To a stirred solution of 11-aminoundecanoic acid $(30.4 \mathrm{~g}, 151 \mathrm{mmol})$ in a mixture $\mathrm{THF} / \mathrm{H}_{2} \mathrm{O}(400 \mathrm{~mL} / 400 \mathrm{~mL})$ 70 was added $\mathrm{NaOH}(9.0 \mathrm{~g}, 225 \mathrm{mmol})$. After $10 \mathrm{~min}$, ditertbutyl dicarbonate $(40.4 \mathrm{~g}, 185 \mathrm{mmol})$ was added and the reaction mixture was stirred for one night at room temperature. The solution was reduced in volume and acidified with $1 \mathrm{~N} \mathrm{HCl}$ which lead to a white precipitate. The 75 solution was taken up with $\mathrm{CH}_{2} \mathrm{Cl}_{2}(400 \mathrm{~mL})$ and washed with $1 \mathrm{~N} \mathrm{HCl}(3 \times 200 \mathrm{~mL})$. The organic layer was then dried over $\mathrm{MgSO}_{4}$, filtered and the filtrate evaporated to obtain a colorless crystallized solid (1, 45.3 g, 99\%); m.p.: $69{ }^{\circ} \mathrm{C} ;{ }^{1} \mathrm{H}$ NMR (200 MHz, $\left.\mathrm{CDCl}_{3}\right) 4.53$ (br, 1H, NH), 3.10 (br, 2H, $\left.80 \mathrm{NH}-\mathrm{CH}_{2}\right), 2.34\left(\mathrm{t}, J=7.4 \mathrm{~Hz}, 2 \mathrm{H}, \mathrm{CH}_{2}-\mathrm{CO}\right), 1.65-1.24(\mathrm{~m}$, $25 \mathrm{H}, \mathrm{C}\left(\mathrm{CH}_{3}\right)_{3}$ and $\left.\mathrm{CH}_{2}\right) ;{ }^{13} \mathrm{C} \mathrm{NMR}\left(50 \mathrm{MHz}, \mathrm{CDCl}_{3}\right) 179.4$ $(\mathrm{COOH}), 156.1(\mathrm{NH}-\mathrm{CO}-\mathrm{O}), 79.1\left(\mathrm{C}\left(\mathrm{CH}_{3}\right)_{3}\right), 40.8\left(\mathrm{NH}-\mathrm{CH}_{2}\right)$,

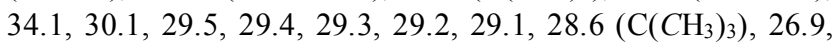
24.8. 


\section{1-(tert-butoxycarbonylamino-undecanoyl-}

[poly(ethyleneglycol)350-monomethylether]-ester (2a). In a $250 \mathrm{~mL}$ round-bottom flask, 11-tert-butoxycarbonylaminoundecanoic acid (1, $18.1 \mathrm{~g}, \quad 60.0 \mathrm{mmol})$, N,N'5 dicyclohexylcarbodiimide (DCC) $(11.1 \mathrm{~g}, 53.8 \mathrm{mmol})$ and dimethylaminopyridine (DMAP) $(2.0 \mathrm{~g}, 16.1 \mathrm{mmol})$ were stirred in $80 \mathrm{~mL}$ of dry dichloromethane under nitrogen. To the solution was added $18.5 \mathrm{~g}(52.8 \mathrm{mmol})$ of poly(ethylene glycol)-monomethyl ether $\left(\mathrm{M}_{\mathrm{n}}\right.$ ca. 350) and the reaction 10 mixture was stirred overnight. After filtration to remove the dicyclohexylurea, the filtrate was concentrated and purified by column chromatography (silica gel, gradient from $\mathrm{CH}_{2} \mathrm{Cl}_{2}$ to $\mathrm{CH}_{2} \mathrm{Cl}_{2} /$ ethanol 9:1 v/v) to obtain a transparent oil $(2,31.16 \mathrm{~g}$, 93\%); ${ }^{1} \mathrm{H}$ NMR (200 MHz, $\left.\mathrm{CDCl}_{3}\right) 4.52$ (br, 1H, NH), 4.21 15 (br, $\left.2 \mathrm{H}, \mathrm{CH}_{2} \mathrm{O}-\mathrm{CO}\right), 3.8-3.5$ (br, $\left.30 \mathrm{H}, \mathrm{OCH}_{2}\right), 3.37$ (s, 3H, $\left.\mathrm{OCH}_{3}\right), 3.08$ (q, $\left.J=6.5 \mathrm{~Hz}, 2 \mathrm{H}, \mathrm{NH}-\mathrm{CH}_{2}\right), 2.31(\mathrm{t}, J=7.5 \mathrm{~Hz}$, $\left.2 \mathrm{H}, \mathrm{CH}_{2}-\mathrm{CO}\right), 1.65-1.23\left(\mathrm{~m}, 25 \mathrm{H}, \mathrm{C}\left(\mathrm{CH}_{3}\right)_{3}\right.$ and $\left.\mathrm{CH}_{2}\right) ;{ }^{13} \mathrm{C}$ NMR (50 MHz, $\left.\mathrm{CDCl}_{3}\right) 174.0(\mathrm{COOH}), 72.0-63.5\left(\mathrm{OCH}_{2}\right)$, $59.2\left(\mathrm{OCH}_{3}\right), 40.7\left(\mathrm{NH}-\mathrm{CH}_{2}\right), 34.3,30.2,29.6,29.5,29.4$, 20 29.3, 29.2, $28.6\left(\mathrm{C}\left(\mathrm{CH}_{3}\right)_{3}\right), 26.9,25.0$; MALDI-TOF[M+Na $\left.{ }^{+}\right]$ $=689.93 \pm \mathrm{n} \times 44$, (calcd: $690.5 \pm \mathrm{n} \times 44)$.

\section{1-aminoundecanoyl-[poly(ethyleneglycol)350-}

monomethylether]-ester (2b). To $30.9 \mathrm{~g}$ of product 2 placed under nitrogen and cooled to $0^{\circ} \mathrm{C}$ was added $40 \mathrm{~mL}$ of a $4 \mathrm{M}$ $25 \mathrm{HCl}$ solution in dioxane. The solution was stirred at $0^{\circ} \mathrm{C}$ for 1 $\mathrm{h}$ and then at room temperature for $2 \mathrm{~h}$. The solvent was evaporated ( $\mathrm{NaOH}$ trap) to yield $27.9 \mathrm{~g}(100 \%)$ of the product as its hydrochloric salt, which was used without further purification; ${ }^{1} \mathrm{H}$ NMR $\left(200 \mathrm{MHz}, \mathrm{CDCl}_{3}\right) 7.96$ (br, 3H, ${ }_{30} \mathrm{NH}_{3}+$ ), 4.11 (br, 2H, CH $\mathrm{H}_{2} \mathrm{O}-\mathrm{CO}$ ), 3.7-3.3 (br, 34H, $\mathrm{OCH}_{2}$ ), $3.23\left(\mathrm{~s}, 3 \mathrm{H}, \mathrm{OCH}_{3}\right), 2.73\left(\mathrm{q}, J=6.9 \mathrm{~Hz}, 2 \mathrm{H}, \mathrm{CH}_{2} \mathrm{~N}\right), 2.29(\mathrm{t}, J$ $\left.=7.3 \mathrm{~Hz}, 2 \mathrm{H}, \mathrm{CH}_{2}-\mathrm{CO}\right), 1.52\left(\mathrm{~m}, 4 \mathrm{H}, \mathrm{CH}_{2} \mathrm{CH}_{2} \mathrm{CO}\right.$ and $\mathrm{CH}_{2} \mathrm{CH}_{2} \mathrm{~N}$ ), 1.24 (br, $\left.12 \mathrm{H}, \mathrm{CH}_{2}\right) ;{ }^{13} \mathrm{C} \mathrm{NMR}\left(50 \mathrm{MHz}, \mathrm{CDCl}_{3}\right)$ $174.0(\mathrm{COOH}), 72.0-63.5\left(\mathrm{OCH}_{2}\right), 59.2\left(\mathrm{OCH}_{3}\right), 40.2(\mathrm{NH}-$ ${ }_{35} \mathrm{CH}_{2}$ ), 34.4, 30.2, 29.4, 29.3, 29.2, 29.1, 27.7, 26.7, 25.1; MALDI-TOF $\left[\mathrm{M}+\mathrm{Na}^{+}\right]=546.23 \pm \mathrm{n} \times 44,\left(\mathrm{NH}_{2}\right.$ form, calcd: $546.4 \pm \mathrm{n} \times 44)$.

\section{di-(11-tert-butoxycarbonylaminoundecanoyl-}

ester)[poly(ethyleneglycol)600] (3a). Same procedure as 2a:

40 product 1 (20.9 g, $69.5 \mathrm{mmol})$, DCC (13.8 g, $66.7 \mathrm{mmol})$ and DMAP (1.9 g, $15.4 \mathrm{mmol})$ in $100 \mathrm{~mL}$ of dry $\mathrm{CH}_{2} \mathrm{Cl}_{2}$, and poly(ethylene glycol) $\left(\mathrm{M}_{\mathrm{n}}\right.$ ca. 600$)$ into $20 \mathrm{~mL}$ of dry $\mathrm{CH}_{2} \mathrm{Cl}_{2}$. Purification of the product by column chromatography (silica gel, gradient from $\mathrm{CH}_{2} \mathrm{Cl}_{2}$ to $\mathrm{CH}_{2} \mathrm{Cl}_{2}$ /ethanol 9:1 v/v) yielded ${ }_{45} 22.9 \mathrm{~g}(65 \%)$ of a white wax; ${ }^{1} \mathrm{H}$ NMR $\left(250 \mathrm{MHz}, \mathrm{CDCl}_{3}\right)$ 4.52 (br, $2 \mathrm{H}, \mathrm{NH}), 4.21$ (br, $\left.4 \mathrm{H}, \mathrm{CH}_{2} \mathrm{O}-\mathrm{CO}\right), 3.8-3.5$ (br, $57 \mathrm{H}$, $\left.\mathrm{OCH}_{2}\right), 3.08$ (q, $\left.J=6.6 \mathrm{~Hz}, 4 \mathrm{H}, \mathrm{NH}-\mathrm{CH}_{2}\right), 2.31(\mathrm{t}, J=7.5 \mathrm{~Hz}$, $\left.4 \mathrm{H}, \mathrm{CH}_{2}-\mathrm{CO}\right), 1.7-1.2\left(\mathrm{~m}, 50 \mathrm{H}, \mathrm{C}\left(\mathrm{CH}_{3}\right)_{3}\right.$ and $\left.\mathrm{CH}_{2}\right) ;{ }^{13} \mathrm{C} \mathrm{NMR}$ (62.9 MHz, $\left.\mathrm{CDCl}_{3}\right) 174.0(\mathrm{COOH}), 70.7,69.3,63.5\left(\mathrm{OCH}_{2}\right)$, $5040.7\left(\mathrm{NH}-\mathrm{CH}_{2}\right), 34.3,30.2,29.6,29.5,29.4,29.3,29.2,28.6$ $\left(\mathrm{C}\left(\mathrm{CH}_{3}\right)_{3}\right), 26.9,25.0 ;$ MALDI-TOF $\left[\mathrm{M}+\mathrm{Na}^{+}\right]=1223.91 \pm$ $\mathrm{n} \times 44$, (calcd: $1223.8 \pm \mathrm{n} \times 44)$.

\section{di-(11-aminoundecanoyl-ester)[poly(ethyleneglycol)600]}

(3b). Same procedure as 2b: 3a (22.9 g, $19.6 \mathrm{mmol})$ in $30 \mathrm{~mL}$ 55 of a $4 \mathrm{M} \mathrm{HCl}$ solution in dioxane yielded $20.3 \mathrm{~g}$ of a yellowish wax; ${ }^{1} \mathrm{H}$ NMR $\left(250 \mathrm{MHz}, \mathrm{CDCl}_{3}\right) 8.13(\mathrm{br}, 6 \mathrm{H}$, $\left.\mathrm{NH}_{3}+\right), 4.21$ (br, 4H, CH $\left.\mathrm{H}_{2} \mathrm{O}-\mathrm{CO}\right), 3.8-3.5\left(\mathrm{br}, 57 \mathrm{H}, \mathrm{OCH}_{2}\right)$, 2.96 (br, 4H, NH-CH ), 2.32 (t, $\left.J=7.4 \mathrm{~Hz}, 4 \mathrm{H}, \mathrm{CH}_{2}-\mathrm{CO}\right)$,
1.75-1.61 (m, 8H, $\mathrm{CH}_{2} \mathrm{CH}_{2} \mathrm{CO}$ and $\left.\mathrm{CH}_{2} \mathrm{CH}_{2} \mathrm{~N}\right), 1.26(\mathrm{br}, 24 \mathrm{H}$, $\left.{ }_{60} \mathrm{CH}_{2}\right) ;{ }^{13} \mathrm{C} \mathrm{NMR}\left(62.9 \mathrm{MHz}, \mathrm{CDCl}_{3}\right) 174.0(\mathrm{COOH}), 70.6$, 69.3, $63.5\left(\mathrm{OCH}_{2}\right), 40.1\left(\mathrm{NH}-\mathrm{CH}_{2}\right), 34.3,29.3,29.2,29.1$, 27.7, 26.7, 25.0; MALDI-TOF[M+Na $\left.{ }^{+}\right]=1023.79 \pm \mathrm{n} \times 44$, ( $\mathrm{NH}_{2}$ form, calcd: $\left.1023.8 \pm \mathrm{n} \times 44\right)$.

Oligomers B1*, B2, B3, B5 and B9. In a round-bottom flask, ${ }_{65}$ products $\mathbf{2} \mathbf{b}$ and $\mathbf{3 b}$ were weighted in adequate proportions (see Table S1) ${ }^{\dagger}$ and dissolved with dry dichloromethane under nitrogen. To these solutions, triethylamine (TEA) and toluene2,4-diisocyanate (TDI) were added and stirred overnight. FTIR measurements confirmed the absence of isocyanate 70 functions. Solutions were washed with $20 \mathrm{~mL}$ of water (with a few drops of ethanol to break the emulsion if necessary) to remove triethylamine salts. The organic layer was evaporated and dried under vacuum to obtain products as yellowish waxes or solids. Oligomers B2, B3, B5 and B9 were 75 characterized by NMR, ${ }^{\dagger}$ SEC (Fig. 2) and MALDI-TOF (Fig. 3).

Monomer B1* was further purified using column chromatography (silica gel, gradient eluent from $\mathrm{CH}_{2} \mathrm{Cl}_{2}$ to $\mathrm{CH}_{2} \mathrm{Cl}_{2}$ /ethanol 9:1 v/v) to give a white wax $(1.04 \mathrm{~g}, 45 \%) ;{ }^{1} \mathrm{H}$ ${ }_{80} \mathrm{NMR}\left(200 \mathrm{MHz}, d_{6}\right.$-DMSO) 8.27 and 7.47 (s, 2H, Ar-NH), $7.70(\mathrm{~d}, J=2.1 \mathrm{~Hz}, 1 \mathrm{H}, \mathrm{Ar}-H), 7.11(\mathrm{dd}, J=8.2$ and $2.1 \mathrm{~Hz}$, $1 \mathrm{H}, \operatorname{Ar}-H), 6.90(\mathrm{~d}, J=8.4 \mathrm{~Hz}, 1 \mathrm{H}, \mathrm{Ar}-H), 6.50$ and $5.94(\mathrm{br}$, $2 \mathrm{H}, \mathrm{CH}_{2}-\mathrm{NH}$ ), 4.11 (br, $4 \mathrm{H}, \mathrm{CH}_{2} \mathrm{O}-\mathrm{CO}$ ), 3.6-3.3 (br, $52 \mathrm{H}$, $\left.\mathrm{OCH}_{2}\right), 3.23\left(\mathrm{~s}, 6 \mathrm{H}, \mathrm{OCH}_{3}\right), 3.04$ (br, 4H, $\left.\mathrm{CH}_{2}-\mathrm{NH}\right), 2.28$ (t, $J$ $\left.{ }_{85}=7.2 \mathrm{~Hz}, 4 \mathrm{H}, \mathrm{CH}_{2}-\mathrm{CO}\right), 2.07\left(\mathrm{~s}, 3 \mathrm{H}, \mathrm{Ar}-\mathrm{CH}_{3}\right), 1.6-1.2(\mathrm{br}$, $\left.32 \mathrm{H}, \mathrm{CH}_{2}\right) ;{ }^{13} \mathrm{C}$ NMR $\left(50 \mathrm{MHz}, d_{6}\right.$-DMSO) $172.9(\mathrm{OC}=\mathrm{O})$, $155.2(\mathrm{NHCONH}), 138.6,138.2,127.6,118.8,109.7(A r)$, 71.3, 69.8, 68.3, $63.1\left(\mathrm{OCH}_{2}\right), 58.1\left(\mathrm{OCH}_{3}\right), 33.4,29.8,29.0$, 28.9, 28.8, 28.7, 28.5, 26.5, $24.5\left(\mathrm{CH}_{2}\right), 17.2\left(\mathrm{Ar}-\mathrm{CH}_{3}\right)$; 90 MALDI-TOF[M+Na $\left.{ }^{+}\right]=1199.83 \pm \mathrm{n} \times 44$, (calcd: $1199.81 \pm$ $\mathrm{n} \times 44$ ); Anal. Calcd for $\mathrm{C}_{59.2} \mathrm{H}_{108.4} \mathrm{~N}_{4} \mathrm{O}_{19.1}: \mathrm{C}, 60.2 ; \mathrm{H}, 9.2 ; \mathrm{N}$, 4.7, Found: C, 59.6; H, 9.3; N, 4.6.

2-\{11-[poly(ethyleneglycol)350-monomethylether)-amido)undecanoyl]-ureido\},4-nitro-toluene (4). To a solution of 95 triphosgene $(0.253 \mathrm{~g}, 0.85 \mathrm{mmol})$ in dry dichloromethane (20 $\mathrm{mL}$ ) placed under nitrogen and room temperature, was added, using a syringe pump $(5 \mathrm{~mL} / \mathrm{h})$, a solution of 2-methyl-5nitroaniline $(0.391 \mathrm{~g}, 2.57 \mathrm{mmol})$ and diisopropylethylamine (DIEA) $(0.47 \mathrm{ml}, 2.72 \mathrm{mmol})$ in $20 \mathrm{~mL}$ dry $\mathrm{CH}_{2} \mathrm{Cl}_{2} .90 \mathrm{~min}$ 100 after the end of addition, a solution of $\mathbf{2 b}(1.71 \mathrm{~g}, 2.9 \mathrm{mmol})$ and TEA $(0.79 \mathrm{~mL}, 5.65 \mathrm{mmol})$ in dry $\mathrm{CH}_{2} \mathrm{Cl}_{2}(20 \mathrm{~mL})$, was rapidly added into the flask and stirred overnight. FT-IR measurement confirmed the absence of isocyanate functions $\left(\sim 2265 \mathrm{~cm}^{-1}\right)$. The solution was washed with water and a few 105 drops of ethanol (to break the emulsion). The organic layer was evaporated and purified by flash chromatography (Reveleris Flash System (Grace), silica $40 \mu \mathrm{m}$, column $40 \mathrm{~g}$, flow 25-30 $\mathrm{mL} / \mathrm{min}$ ) using a gradient eluent from $\mathrm{CH}_{2} \mathrm{Cl}_{2}$ to $\mathrm{CH}_{2} \mathrm{Cl}_{2}$ /ethanol 9:1 v/v ( $\mathrm{Rf} \sim 0,6$ at $\mathrm{CH}_{2} \mathrm{Cl}_{2} /$ ethanol $\left.5: 1 \mathrm{v} / \mathrm{v}\right)$ 110 to obtain an oil $(1.79 \mathrm{~g}, 95 \%) ;{ }^{1} \mathrm{H}$ NMR $\left(200 \mathrm{MHz}, d_{6^{-}}\right.$ DMSO) 8.96 (d, J=2.4 Hz, 1H, Ar- H), 7.96 (s, 1H, Ar-NH), $7.70(\mathrm{dd}, J=8.3 \mathrm{~Hz}$ and $2.4 \mathrm{~Hz}, 1 \mathrm{H}, \mathrm{Ar}-H), 7.38(\mathrm{~d}, J=8.3 \mathrm{~Hz}$, $1 \mathrm{H}, \operatorname{Ar}-H), 6.83\left(\mathrm{t}, J=5.4 \mathrm{~Hz}, 1 \mathrm{H}, \mathrm{CH}_{2}-\mathrm{NH}\right), 4.11$ (br, $2 \mathrm{H}$, $\mathrm{CH}_{2}$-OCO), 3.3-3.6 (br, $\left.35 \mathrm{H}, \mathrm{CH}_{2}-\mathrm{O}\right), 3.23$ (s, $\left.3 \mathrm{H}, \mathrm{CH}_{3}-\mathrm{O}\right)$, 1153.11 (q, $J=6.0 \mathrm{~Hz}, 2 \mathrm{H}, \mathrm{CH}_{2}-\mathrm{NH}$ ), 2.29 (s and t, $5 \mathrm{H}, \mathrm{Ar}-\mathrm{CH}_{3}$ and $\mathrm{CH}_{2}-\mathrm{CO}$ ), 1.2-1.6 (br, $\left.16 \mathrm{H}, \mathrm{CH}_{2}\right) ;{ }^{13} \mathrm{C} \mathrm{NMR}\left(50 \mathrm{MHz}, d_{6^{-}}\right.$ 
DMSO) $172.9(\mathrm{OC}=\mathrm{O}), 154.9(\mathrm{NHCONH}), 146.1,139.5$, 133.3, 130.9, 115.6, $112.7(A r), 71.3,69.8,68.3,63.1\left(\mathrm{OCH}_{2}\right)$, $58.1\left(\mathrm{OCH}_{3}\right), 39.0\left(\mathrm{CH}_{2}-\mathrm{NH}\right), 33.4,29.6,29.0,28.9,28.8$, $28.7,28.5,26.5,24.5\left(\mathrm{CH}_{2}\right), 18.2\left(\mathrm{Ar}-\mathrm{CH}_{3}\right)$; MALDI$5 \mathrm{TOF}\left[\mathrm{M}+\mathrm{Na}^{+}\right]=768.39 \pm \mathrm{n} \times 44$, (calcd: $\left.768.6 \pm \mathrm{n} \times 44\right)$.

2-\{11-[poly(ethyleneglycol)350-monomethylether)-amido)undecanoyl]-ureido $\}$,4-amino-toluene (5). A solution of 4 (1.71 g, $2.34 \mathrm{mmol})$, cyclohexene $(2 \mathrm{~mL}, 19.7 \mathrm{mmol})$ and palladium $(10 \%$ on carbon $)(0.08 \mathrm{~g}, 2.28 \mathrm{mmol})$ in 10 isopropanol $(10 \mathrm{ml})$ was stirred under reflux during 5 days, filtered on Celite and evaporated before flash chromatography (Reveleris Flash System (Grace), silica $40 \mu \mathrm{m}$, column $40 \mathrm{~g}$, flow $30 \mathrm{~mL} / \mathrm{min}$ ) with a gradient eluent from $\mathrm{CH}_{2} \mathrm{Cl}_{2}$ to $\mathrm{CH}_{2} \mathrm{Cl}_{2} /$ ethanol $8: 2 \mathrm{v} / \mathrm{v}$ ( $\mathrm{Rf} \sim 0,45$ at $\mathrm{CH}_{2} \mathrm{Cl}_{2} /$ ethanol $8: 2 \mathrm{v} / \mathrm{v}$ ) 15 to produce a yellish wax $(0.532 \mathrm{~g}, 32 \%) ;{ }^{1} \mathrm{H}$ NMR $(200 \mathrm{MHz}$, $d_{6}$-DMSO) $7.28(\mathrm{~s}, 1 \mathrm{H}, \operatorname{Ar}-\mathrm{N} H), 7.12(\mathrm{~d}, J=2.3 \mathrm{~Hz}, 1 \mathrm{H}, \mathrm{Ar}-$ $H), 6.72(\mathrm{~d}, J=8.2 \mathrm{~Hz}, 1 \mathrm{H}, \mathrm{Ar}-H), 6.41\left(\mathrm{t}, J=5.6 \mathrm{~Hz}, 1 \mathrm{H}, \mathrm{CH}_{2}-\right.$ $\mathrm{NH}), 6.10(\mathrm{dd}, J=7.9 \mathrm{~Hz}$ and $2.3 \mathrm{~Hz}, 1 \mathrm{H}, \mathrm{Ar}-H), 4.71(\mathrm{~s}, 2 \mathrm{H}$, $\mathrm{NH}_{2}$ ), 4.11 (br, 2H, CH $\left.\mathrm{H}_{2} \mathrm{OCO}\right), 3.3-3.6$ (br, 34H, $\left.\mathrm{CH}_{2}-\mathrm{O}\right)$, 203.23 (s, 3H, CH$H_{3}-\mathrm{O}$ ), 3.04 (q, J=6.0 Hz, 2H, CH$\left.H_{2}-\mathrm{NH}\right), 2.29$ (t, $\mathrm{J}=7.3 \mathrm{~Hz}, 2 \mathrm{H}, \mathrm{CH}_{2}-\mathrm{CO}$ ), 1.99 (s, 3H, Ar-CH $), 1.2-1.6(\mathrm{br}$, $\left.16 \mathrm{H}, \mathrm{CH}_{2}\right) ;{ }^{13} \mathrm{C}$ NMR (50 MHz, $d_{6}$-DMSO) $172.9(\mathrm{OC}=\mathrm{O})$, 155.3 (NHCONH), 146.8, 138.5, 130.1, 113.6, 108.1, 106.7 $(A r), 71.3,69.8,68.3,63.1\left(\mathrm{OCH}_{2}\right), 58.1\left(\mathrm{OCH}_{3}\right), 39.0\left(\mathrm{CH}_{2}-\right.$ $\left.{ }_{25} \mathrm{NH}\right), 33.4,29.8,29.0,28.9,28.8,28.7,28.5,26.5,24.5\left(\mathrm{CH}_{2}\right)$, $17.1\left(\mathrm{Ar}-\mathrm{CH}_{3}\right) ;$ MALDI-TOF $\left[\mathrm{M}+\mathrm{Na}^{+}\right]=694.36 \pm \mathrm{n} \times 44$, (calcd: $694.4 \pm \mathrm{n} \times 44$ ).

Dimer B2*. To a solution of triphosgene $(73 \mathrm{mg}, 0.24 \mathrm{mmol})$ in dry dichloromethane $(\sim 10 \mathrm{~mL})$ placed under nitrogen and 30 room temperature, was added using a syringe pump $(5 \mathrm{~mL} / \mathrm{h})$, a solution of $5(0.516 \mathrm{~g}, 0.74 \mathrm{mmol})$ and DIEA $(130 \mu \mathrm{L}, 0.76$ mmol) in $20 \mathrm{~mL}$ dry $\mathrm{CH}_{2} \mathrm{Cl}_{2}$. $2 \mathrm{~h}$ after the end of addition, a solution of $\mathbf{3 b}(0.335 \mathrm{~g}, 0.32 \mathrm{mmol})$ and TEA $(205 \mu \mathrm{L}, 1.47$ $\mathrm{mmol})$ in dry $\mathrm{CH}_{2} \mathrm{Cl}_{2}(20 \mathrm{~mL})$, was rapidly added into the

35 flask. After 3h, FT-IR measurement confirmed the absence of isocyanate functions $\left(\sim 2265 \mathrm{~cm}^{-1}\right)$. The solution was washed with water (no $\mathrm{MgSO}_{4}$ drying), reduced in volume, and then purified by flash chromatography (Reveleris Flash System (Grace), silica $40 \mu \mathrm{m}$, column $12 \mathrm{~g}$, flow 25-30 $\mathrm{mL} / \mathrm{min}$ ) 40 using a gradient eluent from $\mathrm{CH}_{2} \mathrm{Cl}_{2}$ to $\mathrm{CH}_{2} \mathrm{Cl}_{2} /$ ethanol $8: 2 \mathrm{v} / \mathrm{v}$ $\left(\mathrm{R}_{\mathrm{f}} \sim 0,3\right.$ at $\mathrm{CH}_{2} \mathrm{Cl}_{2}$ /ethanol $\left.5: 1 \mathrm{v} / \mathrm{v}\right)$ to give a brown wax $(0.697 \mathrm{~g}, 80 \%)$; ${ }^{1} \mathrm{H}$ NMR $\left(250 \mathrm{MHz}, d_{6}\right.$-DMSO) $8.25(\mathrm{~s}, 2 \mathrm{H}$, $\operatorname{Ar}-\mathrm{N} H), 7.70(\mathrm{~d}, J=2.1 \mathrm{~Hz}, 2 \mathrm{H}, \operatorname{Ar}-H), 7.46$ (s, 2H, Ar-NH), $7.12(\mathrm{dd}, J=8.2 \mathrm{~Hz}$ and $2.1 \mathrm{~Hz}, 1 \mathrm{H}, \operatorname{Ar}-H), 6.90(\mathrm{~d}, J=8.4$ $\left.{ }_{45} \mathrm{~Hz}, 2 \mathrm{H}, \mathrm{Ar}-H\right), 6.49$ (t, $\left.J=5.6 \mathrm{~Hz}, 2 \mathrm{H}, \mathrm{CH}_{2}-\mathrm{NH}\right), 5.95$ (t, $J=$ $5.7 \mathrm{~Hz}, 2 \mathrm{H}, \mathrm{CH}_{2}-\mathrm{NH}$ ), 4.11 (br, $8 \mathrm{H}, \mathrm{CH}_{2}-\mathrm{OCO}$ ), 3.3-3.6 (br, $130 \mathrm{H}, \mathrm{CH}_{2}-\mathrm{O}$ ), 3.23 (s, 6H, $\mathrm{CH}_{3}-\mathrm{O}$ ), 3.04 (br, $8 \mathrm{H}, \mathrm{CH}_{2}-\mathrm{NH}$ ), $2.28\left(\mathrm{t}, \mathrm{J}=7.3 \mathrm{~Hz}, 8 \mathrm{H}, \mathrm{CH}_{2}-\mathrm{CO}\right), 2.07$ (s, 6H, Ar- $\left.\mathrm{CH}_{3}\right), 1.2-$ $1.6\left(\mathrm{br}, 64 \mathrm{H}, \mathrm{CH}_{2}\right) ;{ }^{13} \mathrm{C} \mathrm{NMR}\left(62.5 \mathrm{MHz}, d_{6}\right.$-DMSO) 172.9 ${ }_{50}(\mathrm{OC}=\mathrm{O}), 155.2$ and $155.3(\mathrm{NHCONH}), 138.7,138.3,129.9$, 118.8, 111.5, $109.8(A r), 71.3,69.8,68.3,63.0\left(\mathrm{OCH}_{2}\right), 58.1$ $\left(\mathrm{OCH}_{3}\right), 39.0\left(\mathrm{CH}_{2}-\mathrm{NH}\right), 33.4,29.8,29.0,28.9,28.8,28.7$, 28.5, 26.4, $24.5\left(\mathrm{CH}_{2}\right), 17.2\left(\mathrm{Ar}-\mathrm{CH}_{3}\right) ; \mathrm{MALDI}-\mathrm{TOF}\left[\mathrm{M}+\mathrm{Na}^{+}\right]$ $=2418.61 \pm \mathrm{n} \times 44$, (calcd: $2418.4 \pm \mathrm{n} \times 44)$.

\section{${ }_{55}$ Analyses}

Size exclusion chromatography (SEC). Measurements were performed in a $1 \mathrm{~g} / \mathrm{L} \mathrm{LiBr}$ solution in dimethylformamide (DMF) at a flow rate of $0.8 \mathrm{~mL} / \mathrm{min}$ using a Waters HPLC 515 pump, a Viscotek VE 5200 automatic injector and two ${ }_{60}$ columns thermostated at $60^{\circ} \mathrm{C}$ (PSS GRAM, $1000 \AA, 10 \mu \mathrm{m}, 8$ $\mathrm{mm} \times 300 \mathrm{~mm}$ and PSS GRAM, 30 $, 10 \mu \mathrm{m}, 8 \mathrm{~mm}$ x 300 $\mathrm{mm})$. Polymers were detected by refractive index, viscosimetry (Viscotek Dual Model 250) and light scattering (Wyatt Technology MiniDAWN). Molar masses were ${ }_{65}$ computed with Omnisec v4.1 software, based on a polyethylene oxide (Polymer Laboratories) calibration curve.

NMR analysis. ${ }^{1} \mathrm{H}$ and ${ }^{13} \mathrm{C}$ NMR spectra were recorded on a Bruker Avance 200 or ARX 250 spectrometer operating at proton frequency of $200 \mathrm{MHz}$ or $250 \mathrm{MHz}$ respectively. ${ }_{70} \mathrm{CDCl}_{3}$ was suitable for most compounds except for final products, which required the use of $d 6-\mathrm{DMSO}$ to avoid aggregation of bis-urea moieties.

MALDI TOF spectrometry. $10 \mu \mathrm{L}$ of the polymer solution ( $5 \mathrm{~g} \mathrm{~L}^{-1}$ in THF) was mixed with $20 \mu \mathrm{L}$ of the matrix solution 75 (1,8-dihydroxy-9[10H]-anthracenone (dithranol), $25 \mathrm{~g} \mathrm{~L}^{-1}$ in $\mathrm{THF})$, and $10 \mu \mathrm{L}$ of a sodium iodide solution $\left(20 \mathrm{~g} \mathrm{~L}^{-1}\right.$ in THF). A $1 \mu \mathrm{L}$ portion of the final solution was deposited onto the sample target. The MALDI mass spectra represent averages over 256 consecutive laser shots. Standards 80 (polystyrenes of known structure, $\mathrm{M}_{\mathrm{n}}=1500$ and $3280 \mathrm{~g} \mathrm{~mol}^{-1}$ purchased from Polymer Standards Service) were used to calibrate the mass scale. Samples were analysed with an Autoflex III Smartbeam (Bruker) using the flexControl V3 software. The data were treated with the flexAnalysis V3 85 software.

Solubility tests. Samples were prepared by weighting product and solvent directly into vials, which were gently warmed during 2-5 minutes with a hair-dryer and shaken on an oscillating table for at least $24 \mathrm{~h}$ at room temperature.

90 Viscosimetry. Solutions were filtered on PTFE membranes (0.45 $\mu \mathrm{m}$ porosity). Measurements were performed with an automatic Anton-Paar AMVn viscometer (capillary internal diameter $1.8 \mathrm{~mm}$; ball diameter $1.5 \mathrm{~mm}$ ), tilted at an angle of $50^{\circ}$, and repeated 6 times.

${ }_{95}$ Small Angle Neutron Scattering (SANS). Measurements were made at the LLB (Saclay, France) on the Pace instrument, at several distance-wavelength combinations to cover at least the $2.410^{-3}$ to $0.37 \AA^{-1} q$-range, where the scattering vector $q$ is defined as usual, assuming elastic scattering, as $q=$ $100(4 \pi / \lambda) \sin (\theta / 2)$, where $\theta$ is the angle between incident and scattered beam. Data were corrected for the empty cell signal and the solute and solvent incoherent background. A light water standard was used to normalize the scattered intensities to $\mathrm{cm}^{-1}$ units.

${ }_{105}$ Cryogenic Transmission Electron Microscopy (cryoTEM). Samples were fast frozen in liquid ethane. The cryoTEM images were recorded using a JEOL JEM2100F equipped with a GATAN Ultrasean 4000 camera. Image acquisition was performed with a low electron beam intensity (10 electron $\AA^{-2}$ $\left.110 \mathrm{~s}^{-1}\right)$.

\section{Results and discussion}




$$
\text { (n) }
$$

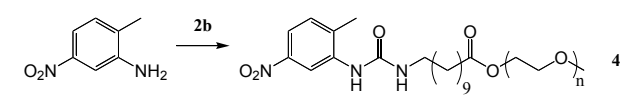

Scheme 2 Dimer B2* synthesis.

\section{Synthesis}

In a first step, polyethylene glycol connected to one or two amino groups through a hydrophobic spacer were prepared by esterification of a boc-protected aminoacid (Scheme 1). In a 10 second step, both amines were reacted together with toluene diisocyanate to afford bis-urea oligomers, the molar mass of which was varied by changing the ratio of monoamine $\mathbf{2 b}$ to diamine $\mathbf{3 b}(\mathrm{r}=[\mathbf{2 b}] /[\mathbf{3 b}])$, while maintaining the stoichiometry between amine and isocyanate functions

$15\left(\left[\mathrm{NH}_{2}\right] /[\mathrm{NCO}]=1\right)$. The resulting oligomers were characterized by NMR, SEC and MALDI-TOF mass spectrometry. ${ }^{1} \mathrm{H}$ and ${ }^{13} \mathrm{C}$ NMR spectra are in agreement with the expected structures ${ }^{\dagger}$ and the integration of the aromatic protons relative to the POE methyl protons affords the average 20 number of bis-urea moieties per chain (Table 1). SEC confirms the expected increase in molar mass when the monoamine to diamine ratio $\mathrm{r}$ is reduced (Fig. 2a). In addition, a peak at an elution volume larger than for bisurea $\mathbf{B} 1 *$ is detected. The absence of unreacted amine and the MALDI${ }_{25}$ TOF results (see below) indicate that this peak is due to the presence of a low amount of cyclic species. ${ }^{8}$ A typical MALDI-TOF spectrum obtained for oligomer $\mathbf{B 3}$ is shown in Fig. 3. Although only the low molar mass fraction of the sample is detected, the agreement between calculated and 30 measured masses allows to confirm the structure of the linear monomer bearing one hydrophobic bisurea group and two methoxy-terminated POE groups and of the cyclic monomer bearing one hydrophobic bisurea group and one POE group.

In order to evaluate the influence of polydispersity, a dimer 35 was also prepared, starting from 2-amino-4-nitrotoluene (Scheme 2), following a strategy previously established for non-symmetrical bis-ureas. ${ }^{9}$ NMR and MALDI TOF confirm the structure dimer B2* and SEC (Fig. 2b) shows that the polydispersity of $\mathbf{B 2} *$ is much narrower than that of sample ${ }_{40} \mathbf{B 2}$ obtained by statistical condensation.

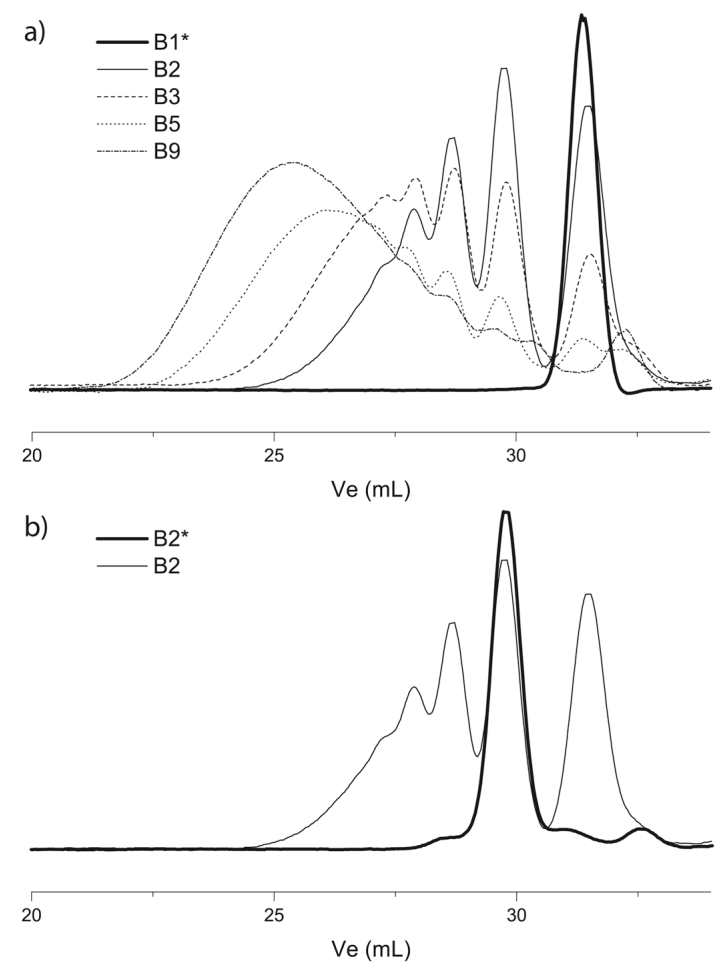

Fig. 2 SEC traces for oligomers (a) and dimer B2* (b).

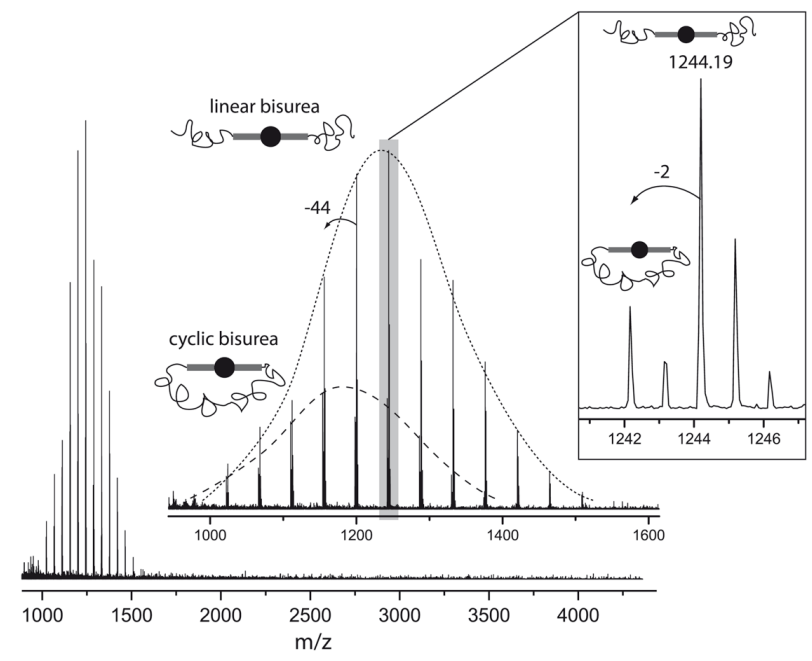

Fig. 3 MALDI-TOF spectrum for oligomer B3. 
Table 1 Molar masses of oligomers

$\begin{array}{cccccc} & \mathrm{n}_{\text {theo }} & \mathrm{n}_{\mathrm{NMR}} & \begin{array}{c}\mathrm{M}_{\mathrm{n}} \\ (\mathrm{g} / \mathrm{mol})\end{array} & \begin{array}{c}\mathrm{M}_{\mathrm{w}} \\ (\mathrm{g} / \mathrm{mol})\end{array} & \mathrm{M}_{\mathrm{w}} / \mathrm{M}_{\mathrm{n}} \\ \text { B1* } & 1.0 & 1.0 & 1190 & 1200 & 1.01 \\ \text { B2* }^{*} & 2.0 & 1.8 & 2130 & 2410 & 1.13 \\ \mathbf{B 2} & 2.0 & 1.9 & 2420 & 3930 & 1.63 \\ \mathbf{B 3} & 3.0 & 3.0 & 3245 & 6000 & 1.85 \\ \mathbf{B 5} & 5.0 & 4.9 & 4640 & 10200 & 2.19 \\ \text { B9 } & 9.1 & 9.0 & 5750 & 14000 & 2.44\end{array}$

$\mathrm{n}_{\text {theo }}\left(\right.$ resp. $\mathrm{n}_{\mathrm{NMR}}$ ): number of bis-urea moieties per chain, based on reactant ratio (resp. on NMR analysis); molar masses determined by SEC in DMF

\section{${ }_{5}$ Solubility}

The solubility of the oligomers was tested at a concentration of $1 \%(\mathrm{w} / \mathrm{w})$ in various polar solvents (Table 2 and Fig. 4). The monomer B1* dissolves readily in water: a clear solution forms within a few minutes of shaking at room 10 temperature. In contrast, none of the polymers could be dissolved in water, even after a prolonged period of heating, of sonicating or by using a low amount of co-solvent (tetrahydrofuran). The hydrophilic/hydrophobic balance of all the samples is the same, therefore the insolubility of the 15 oligomers must be a consequence of the presence of several associating groups per chain. A decreasing solubility with increasing molar mass is a well-known entropic effect in polymer science, however in the present case, the influence of the number of sticker per chain is drastic because already the 20 dimer B2 is insoluble. In order to check if this low solubility is due to polydispersity, i.e. to the presence of macromolecules with more than 2 stickers per chain, dimer B2* was also tested. Its insolubility unambiguously establishes that the presence of 2 stickers per chain hinders 25 the solubility in water. In contrast, the solubility of the oligomers is significantly improved in polar organic solvents. In particular, in methanol dimer $\mathbf{B 2}$ * is soluble and oligomers B2 and B3 form gels after gentle heating. Therefore further characterization was performed in methanol and compared to 30 the results for monomer $\mathbf{B} 1$ * in water and methanol.

Table 2 Solubility data

$\begin{array}{ccccc} & \text { acetonitrile } & \text { methanol } & \text { ethanol } \\ \text { B1* } & \text { Sater } & \text { S } & \text { S } & \text { S } \\ \text { B2* } & \text { I } & \text { G } & \text { S } & \text { S } \\ \text { B2 } & \text { I } & \text { PG } & \text { G } & \text { PS } \\ \text { B3 } & \text { I } & \text { PG } & \text { G } & \text { PS } \\ \text { B5 } & \text { I } & \text { I } & \text { PS } & \text { I } \\ \text { B9 } & \text { I } & \text { I } & \text { PS } & \text { I }\end{array}$

S: fluid solution; PS: partially soluble (fluid solution with solid deposit); G: homogeneous gel; PG: partial gel (gel with solid deposit)

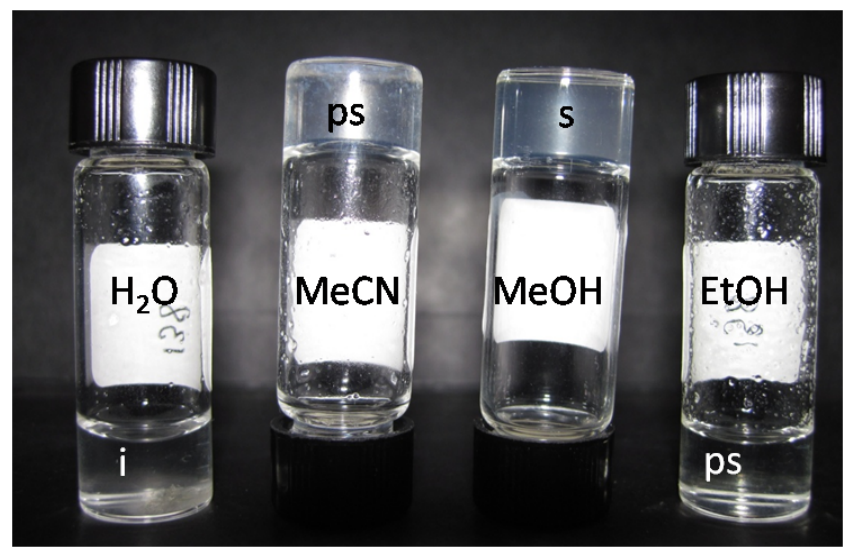

Fig. 4 Solubility tests for solutions of oligomer B2 (1\%).

\section{Self-assembly in water}

Capillary viscosity measurements show that aqueous solutions of bis-urea $\mathbf{B} 1 *$ are significantly viscous $\left(\eta / \eta_{0}=5\right)$ 40 at a concentration of $1 \%(\mathrm{w} / \mathrm{w})$. Therefore the presence of large anisotropic self-assemblies is expected. ${ }^{3-5}$ This was confirmed by cryoTEM and SANS analysis. Fig. 5 shows the presence of micrometer long filaments. In fact, close inspection of the images reveals the presence of two 45 populations of filaments: closely packed filaments with a diameter of $8.8 \pm 0.5 \mathrm{~nm}$ and isolated filaments with a diameter of $11.0 \pm 0.8 \mathrm{~nm}$. The solutions were also analysed by SANS (Fig. 6): the low angle region of the scattered intensity shows a perfect $\mathrm{q}^{-1}$ dependence over more than a 50 decade, which is characteristic for long and rigid fibrillar objects. In principle, the characteristic dimensions of the scattering objects can be deduced from a fit to a form factor calculated according to a suitable geometrical model. In the present case, the use of a form factor taking into account two 55 populations of infinitely long rigid filaments with a uniform scattering length density profile and a circular cross-section ${ }^{10}$ afforded an excellent fit over the whole $q$ range. The parameters deduced from the fit are $41 \%$ of thin filaments (with a cross-section diameter of $5.6 \mathrm{~nm}$ and a mass per unit 60 length corresponding to 3.0 molecules in the cross-section) and $59 \%$ of thicker filaments (with a cross-section diameter of $7.5 \mathrm{~nm}$ and a mass per unit length corresponding to 5.4 molecules in the cross-section). However, one has to note that the use of a form factor for infinitely long rigid filaments with ${ }_{65}$ an elliptical cross-section ${ }^{4}$ also affords an excellent fit over the whole $\mathrm{q}$ range. The exact determination of the fine structure of the filaments would therefore require further investigation. Nevertheless, the SANS and cryoTEM results are coherent and show that the solutions contain very long 70 filaments with a cross-section diameter that is close to the largest dimension of a B1* molecule in a fully extended conformation $(8.5 \mathrm{~nm})$. Based on these microscopic and scattering data, it is reasonable to assume a self-assembled structure similar to related systems where hydrophobic

75 interactions induce aggregation (both in the direction of the filament and within the cross-section), and is reinforced by hydrogen bonds along the filament direction. ${ }^{4}$ 


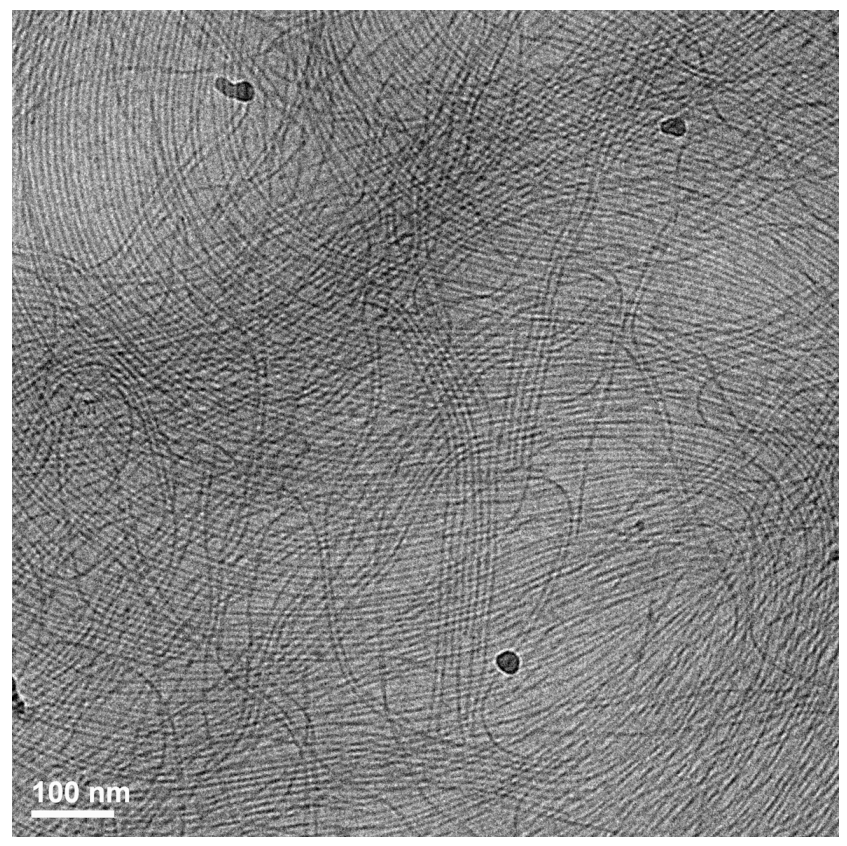

Fig. 5 CryoTEM for monomer B1* solution ( $0.25 \%$ in water).

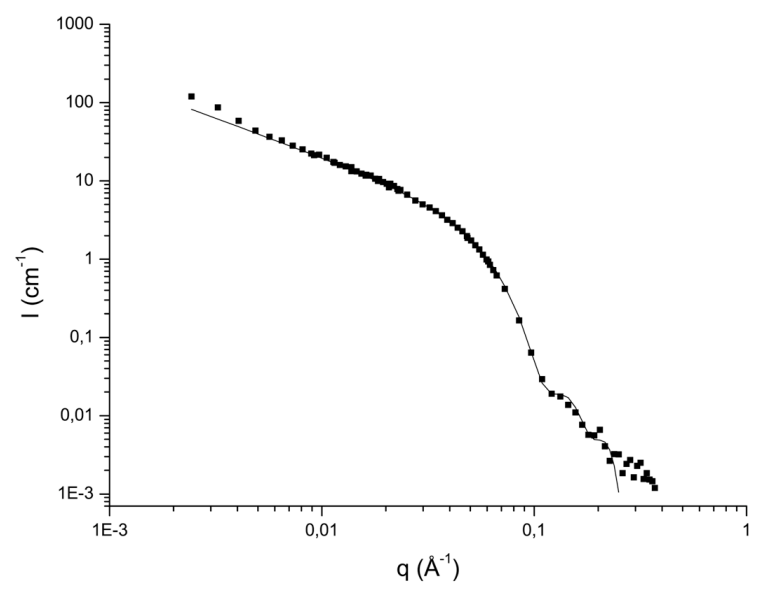

Fig. 6 SANS intensity (I) versus scattering vector (q) for monomer B1 * 5 solution in $\mathrm{D}_{2} \mathrm{O}$ at $10 \mathrm{~g} / \mathrm{L}$ and $25^{\circ} \mathrm{C}$. The plain curve is a fit according to a model for two populations of long rigid filaments with a circular crosssection (respective cross-section diameters: 5.6 and $7.5 \mathrm{~nm}$ ).

\section{Self-assembly in methanol}

The better solubility of the samples in methanol allows a 10 more straightforward comparison of the effect of the macromolecular structure. The bis-urea monomer B1* and the dimer B2* form clear and fluid $\left(\eta / \eta_{0}<1.05\right)$ solutions at $1 \%$ in methanol, whereas the polydisperse dimer $\mathbf{B 2}$ and trimer $\mathbf{B 3}$ form slightly turbid gels (Fig. 4), and the longer oligomers B5 15 and B9 are only partially soluble. The strong influence of the macromolecular structure on the supramolecular structure is confirmed by SANS (Fig. 7). First of all, monomer B1* displays a low scattering intensity which is characteristic of a low molar mass structure. A fit to a Gaussian chain form 20 factor yields a molar mass of $690 \mathrm{~g} / \mathrm{mol}$ and a radius of gyration of $1.1 \mathrm{~nm}$ indicating that the monomer $\mathbf{B 1}$ * is virtually not assembled in methanol. There is thus a strong solvent effect: in methanol the solvophobic interactions are probably much weaker than in water so that the assembly ${ }_{25}$ formed by monomer $\mathbf{B 1}$ * in water is not stable in methanol at the same concentration. In contrast, short oligomers $\mathbf{B} 2$ and B3 display a strong scattering intensity, with $\mathrm{q}^{-1}$ dependence typical of long and rigid objects. Even though the stickers on B1* and $\mathbf{B 2}$ are the same, the weakness of the interaction is 30 apparently compensated in the case of $\mathbf{B 2}$ by the fact that several stickers are present on each chain. A possible explanation involves the probably cooperative growth of the filaments. Indeed, it is well-known that worm-like micelles display a cooperative growth, in the sense that the amphiphilic 35 monomers assemble only above a critical micellar concentration (cmc). ${ }^{11}$ The growth of bis-urea based supramolecular polymers is also cooperative: formation of a dimer is less favoured than elongation of an existing oligomer. ${ }^{12}$ Therefore, the growth of these objects is possible 40 only above a certain concentration where small nuclei become stable. In the present case, one can assume that when more than 2 stickers are present on a macromolecule, the local concentration of stickers is large enough for a stable nucleus to form, ${ }^{13}$ which in turn allows long filaments to form, 45 whereas the monomer present at the same macroscopic concentration cannot assemble.

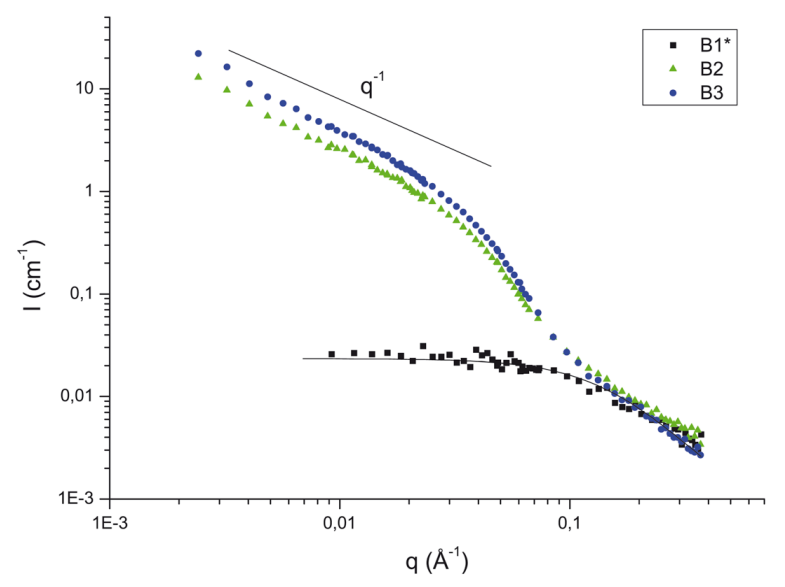

Fig. 7 SANS intensity (I) versus scattering vector (q) for monomer B1* and oligomers $\mathbf{B} 2$ and $\mathbf{B 3}$ solutions in $\mathrm{CD}_{3} \mathrm{OD}$ at $10 \mathrm{~g} / \mathrm{L}$ and $25^{\circ} \mathrm{C}$.

\section{${ }_{50}$ Conclusion}

We have described the synthesis of macromolecular amphiphiles of various molar masses containing well-defined hydrophobic groups incorporating urea moieties. All compounds have the same proportion of associative ${ }_{55}$ hydrophobic groups and solubilising POE chains. However, a strong influence of both the number of associative groups per chain and its polydispersity has been demonstrated. In water, where the interactions between stickers are strong, the monomer self-assembles into filaments, but all other 60 compounds with more than one sticker per chain are insoluble. In methanol, where the interactions between stickers are weaker, neither the monomer nor the monodispersed dimer are assembled, whereas polydispersed chains with an average number of stickers per chain of 2 or 3 self-assemble into ${ }_{65}$ filaments, leading to macroscopic gelation. 
We thank Eric Larquet (Institut de minéralogie et de physique des milieux condensés (IMPMC), Sorbonne Universités UPMC and CNRS UMR 7590) for cryo-TEM analysis.

\section{${ }_{5}$ Notes and references}

${ }^{a}$ UPMC Univ Paris 06, UMR 7610, Chimie des Polymères, 75005 Paris, France; CNRS, UMR 7610, Chimie des Polymères, 75005 Paris, France. E-mail: laurent.bouteiller@upmc.fr

${ }^{b}$ BASF ISIS, 8 Allée Gaspard Monge, 67083 Strasbourg, France

$10{ }^{c}$ Laboratoire Léon Brillouin, UMR 12 CNRS-CEA, 91191 Gif-sur-Yvette Cedex, France

$\dagger$ Electronic Supplementary Information (ESI) available: Additional

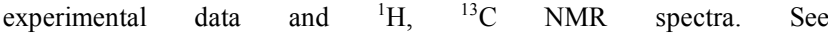
DOI: $10.1039 / \mathrm{b} 000000 \mathrm{x} /$

151 (a) M. Petersheim and D. H. Turner, Biochemistry, 1983, 22, 256; (b) E. Protozanova, P. Yakovchuk and M. D. Frank-Kamenetskii, J. Mol. Biol., 2004, 342, 775.

2 (a) J. H. K. K. Hirschberg, L. Brunsveld, A. Ramzi, J. A. J. M. Vekemans, R. P. Sijbesma and E. W. Meijer, Nature, 2000, 407, 167;

20 (b) H. Fenniri, P. Mathivanan, K. L. Vidale, D. M. Sherman, K. Hallenga, K. V. Wood and J. G. Stowell, J. Am. Chem. Soc., 2001, 123,3854 .

3 N. Chebotareva, P. H. H. Bomans, P. M. Frederik, N. A. J. M. Sommerdijk and R. P. Sijbesma, Chem. Commun., 2005, 4967.

254 E. Obert, M. Bellot, L. Bouteiller, F. Andrioletti, C. LehenFerrenbach and F. Boué, J. Am. Chem. Soc., 2007, 129, 15601.

5 A. Pal, S. Karthikeyan and R. P. Sijbesma, J. Am. Chem. Soc., 2010, 132, 7842 .

6 (a) T. Annable, R. Buscall, R. Ettelaie and D. Whittlestone, J. Rheol.,

$30 \quad$ 1993, 37, 695; (b) A. Yekta, J. Duhamel, H. Adiwidjaja, P. Brochard and M. A. Winnik, Langmuir, 1993, 9, 881; (c) B. Jeong, S. W. Kim and Y. H. Bae, Adv. Drug Delivery Rev., 2002, 54, 37; (d) A. S. Shedge, A. K. Lele, P. P. Wadgaonkar, D. Hourdet, P. Perrin, C. Chassenieux and M. V. Badiger, Macromol. Chem. Phys., 2005, 206,

35464 .

7 G. Bottari, D. A. Leigh and E. M. Perez, J. Am. Chem. Soc., 2003, $\mathbf{1 2 5}, 13360$.

8 the presence of cyclics means that the average number of bis-urea moieties per chain determined from NMR is in fact slightly larger than the real value.

9 (a) O. Colombani and L. Bouteiller, New J. Chem., 2004, 28, 1373; (b) M. Roman, C. Cannizzo, T. Pinault, B. Isare, B. Andrioletti, P. van der Schoot and L. Bouteiller, J. Am. Chem. Soc., 2010, 132, 16818.

4510 (a) F. Lortie, S. Boileau, L. Bouteiller, C. Chassenieux, B. Demé, G. Ducouret, M. Jalabert, F. Lauprêtre and P. Terech, Langmuir 2002, 18, 7218; (b) L. Bouteiller, O. Colombani, F. Lortie and P. Terech, J. Am. Chem. Soc. 2005, 127, 8893.

11 C. A. Dreiss, Soft Matter, 2007, 3, 956.

5012 (a) V. Simic, L. Bouteiller and M. Jalabert, J. Am. Chem. Soc. 2003, 125, 13148; (b) A. Arnaud and L. Bouteiller, Langmuir 2004, 20, 6858; (c) M. Bellot and L. Bouteiller, Langmuir 2008, 24, 14176.

13 If a dimer is considered to occupy a sphere of radius $10 \mathrm{~nm}$, the sticker concentration in the sphere is $1 \mathrm{~mol} / \mathrm{L}$, i.e. 2 orders of

55 magnitude larger than the macroscopic concentrations used in our experiments. 